\title{
Red ginger wedang to strengthen immune system against covid-19 of children living in an orphanage
}

\author{
Karina Nola Sinamo ${ }^{1 *}$, Nauas Domu Marihot Romauli Hutabarat ${ }^{1}$ \\ ${ }^{1}$ Program studi Ilmu dan Teknologi Pangan, Fakultas Pertanian, Universitas Sumatera Utara \\ *Email: karinanolasinamo@usu.ac.id
}

\begin{abstract}
The outbreak of the corona virus has forced orphanage children to gather at home to carry out learning and playing activities. The activity of gathering in one house can cause a high risk of Covid-19 transmission. The implementation of the community service program carried out by lecturers from the Food Science and Technology Department, Faculty of Agriculture, Universitas Sumatera Utara is a training for making red ginger wedang at LKSA Anak Gembira, Medan Tuntungan, Medan. Red ginger wedang is a drink that is healthy and refreshing for the body, where the aim of this training is that partners can practice it and consume it to maintain their immune system at LKSA Anak Gembira in preventing Covid-19. The training activity for making red ginger drink was attended by 24 people consisting of 2 orphanage owners and 22 orphanage children. After that, the consumption of red ginger was carried out and questionnaires were administered to measure the level of understanding of the benefits and preferences of the respondents towards red ginger after the training was held. The results of the questionnaire show that $93 \%$ respondents understand the benefits of red ginger for health and $87 \%$ like red ginger wedang.
\end{abstract}

Keyword: covid-19, immune system, red ginger wedang, training

\begin{abstract}
Abstrak
Mewabahnya virus corona membuat anak-anak panti asuhan terpaksa harus berkumpul di rumah untuk melakukan kegiatan belajar dan bermain. Kegiatan berkumpul dalam satu rumah tersebut dapat membuat tingginya resiko penularan Covid-19. Pelaksanaan program pengabdian kepada masyarakat yang dilaksanakan oleh tim dari dosen Program Studi Ilmu dan Teknologi Pangan Fakultas Pertanian Universitas Sumatera Utara adalah pelatihan pembuatan wedang jahe merah di LKSA Anak Gembira, Kelurahan Mangga, Kecamatan Medan Tuntungan, Medan. Wedang jahe merah merupakan minuman yang menyehatkan dan menyegarkan tubuh, dimana tujuan pelatihan ini adalah mitra dapat mempraktikkannya dan mengonsumsinya untuk menjaga imunitas tubuh anakanak panti asuhan di LKSA Anak Gembira dalam mencegah penularan Covid-19. Kegiatan pelatihan pembuatan wedang jahe merah ini diikuti oleh 24 orang terdiri dari 2 orang pemilik panti asuhan dan 22 orang anak-anak panti asuhan. Setelah itu, dilakukan kegiatan konsumsi wedang jahe merah dan pemberian kuesioner untuk mengukur tingkat pemahaman manfaat dan kesukaan responden terhadap wedang jahe merah setelah diadakan pelatihan. Hasil kuesioner didapat bahwa $93 \%$ responden memahami manfaat wedang jahe merah bagi kesehatan dan $87 \%$ memiliki kesukaan akan wedang jahe merah.
\end{abstract}

Kata Kunci: covid-19, imunitas tubuh, kesehatan, pelatihan, wedang jahe merah

\section{PENDAhuluan}

Berdasarkan data dari Dinas Kesehatan Kota Medan (2020) bahwa virus corona telah mewabah di beberapa kecamatan yang ada di Kota Medan, salah satunya adalah Kecamatan Medan Tuntungan. Kelurahan Mangga yang terletak di Kecamatan Tuntungan merupakan lokasi dimana 5 orang meninggal dan 45 orang dirawat akibat positif Covid-19 per tanggal 27 Agustus 2020 dan termasuk dalam kategori zona merah. Data pasien positif Covid-19 yang meninggal dan dirawat di Kelurahan Mangga tersebut merupakan data terbesar dibandingkan dengan kelurahan yang lainnya di Kecamatan Medan Tuntungan. Berdasarkan permasalahan tersebut, tim pengabdian kepada masyarakat melakukan kegiatan pengabdian kepada masyarakat di LKSA Anak Gembira yang berlokasi di Kelurahan Mangga dengan tema pencegahan Covid-19. LKSA Anak Gembira 
merupakan Lembaga Kesejahteraan Sosial Anak (LKSA) dengan No. Akte Pendirian 97 Tanggal 26 Nopember 2012 yang memiliki jumlah anak panti asuhan sebanyak 22 orang di dalam panti asuhan dan 15 orang anak di luar panti asuhan.

Kegiatan pengabdian kepada masyarakat yang dilakukan di LKSA Anak Gembira bertujuan untuk mencegah penyebaran virus Corona atau yang disebut juga SARS-CoV-2. Covid-19 adalah penyakit sangat mudah menular yang disebabkan oleh jenis coronavirus dimana penderita Covid-19 dapat mengalami gejala demam, batuk kering dan kesulitan bernafas. Selain gejala tersebut, gejala tambahan lainnya adalah sakit tenggorokan, pilek dan bersin-bersin. Pada penderita yang paling kritis gejala ini dapat berubah menjadi pneumonia dan kegagalan pada organ vital seperti paru-paru.

Wedang jahe merah adalah minuman yang menyehatkan dan menyegarkan tubuh yang bermanfaat menghangatkan tubuh, melancarkan sistem pernafasan, mengatasi rasa mual, dan mengatasi gangguan pencernaan. Pelaksanaan program kegiatan pengabdian kepada masyarakat yaitu pelatihan pembuatan minuman wedang jahe merah bertujuan untuk memberikan pengetahuan cara pembuatan wedang jahe merah kepada mitra dan menjaga kesehatan tubuh anak-anak dengan mengonsumsi wedang jahe merah sehingga anak-anak di LKSA Anak Gembira tidak mudah terkena penyebaran virus Corona.

\section{METODE PELAKSANAAN}

Metoda pelaksanaan program pengabdian kepada masyarakat yang dilaksanakan oleh tim pengabdian kepada masyarakat untuk mengatasi permasalahan dari mitra adalah:

1) Tim pengabdian kepada masyarakat melakukan pelatihan pembuatan minuman wedang jahe merah yaitu minuman yang menyegarkan dan menyehatkan tubuh sehingga mitra dapat mempraktikkannya dan mengonsumsinya untuk menjaga imunitas tubuh anak-anak panti asuhan di LKSA Anak Gembira dalam mencegah penularan Covid-19. Di akhir pelatihan, anak-anak panti asuhan diberi kuesioner berupa pertanyaan mengenai wedang jahe merah yang dihasilkan untuk mengetahui pemahaman terhadap manfaat dan kesukaan akan wedang jahe merah yang dihasilkan,

2) Tim pengabdian kepada masyarakat memberikan tanaman jahe merah agar mitra dapat menanamnya di pekarangan panti asuhan agar mitra tidak kesulitan dalam mendapatkan bahan baku (jahe merah) dalam membuat wedang jahe merah.

3) Tim pengabdian kepada masyarakat memberikan bantuan sabun pencuci tangan cair, hand sanitizer, dan masker kain dan cara penggunaan masker kain kepada anak-anak panti asuhan di LKSA Anak Gembira yang dapat dipakai saat belajar dan bermain bersama di dalam rumah atau mereka terpaksa keluar rumah untuk kegiatan yang mendesak,

4) Tim pengabdian kepada masyarakat memberikan bantuan kotak obat dan bantuan pangan pokok seperti beras, telur, susu, gula, dan minyak goreng dan dalam membantu perekonomian di LKSA Anak Gembira.

\section{HASIL DAN PEMBAHASAN}

Covid-19 atau penyakit menular yang disebabkan oleh virus Corona atau yang disebut juga SARSCoV-2 dapat menyebar dari orang ke orang melalui percikan-percikan dari hidung atau mulut yang keluar saat orang yang terinfeksi Covid-19 batuk, bersin, atau berbicara. Oleh karena itu, perlunya pelatihan pembuatan minuman yang menyehatkan yaitu wedang jahe merah untuk dikonsumsi anakanak panti asuhan di LKSA Anak Gembira agar tidak mudah terkena virus Covid-19. LKSA Anak Gembira beralamat di Jalan Tembakau Raya No. 83 Perumnas Simalingkar, Kelurahan Mangga, Kecamatan Medan Tuntungan, Medan dengan Mitra Bapak Drs. Besri Ritonga selaku Ketua LKSA Anak Gembira (Gambar 1). 


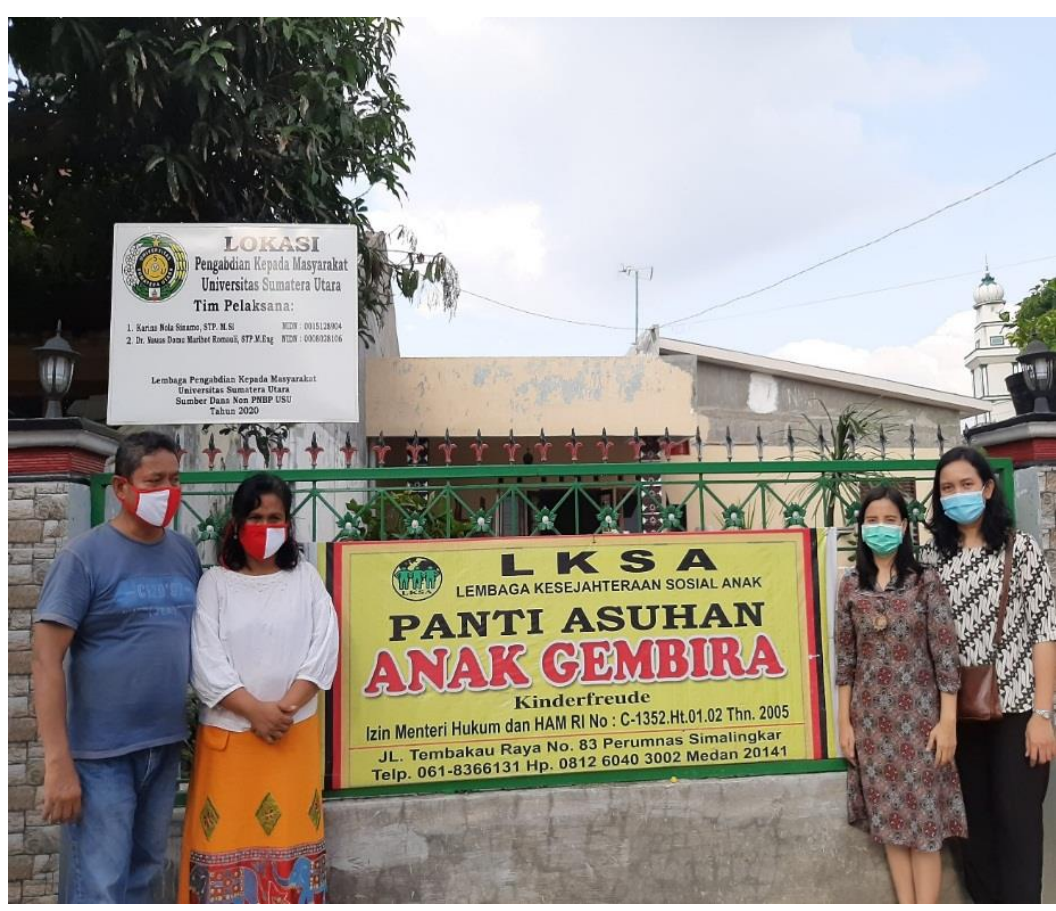

Gambar 1. Tim pengabdian kepada masyarakat USU bersama mitra LKSA Anak Gembira

Wedang jahe merah adalah minuman tradisional Indonesia yang berkhasiat bagi kesehatan manusia yaitu menghangatkan tubuh, melancarkan sistem pernafasan, mengatasi rasa mual, dan mengatasi gangguan pencernaan. Penggunaan jahe merah pada wedang jahe merah karena jahe merah mempunyai banyak keunggulan dibandingkan dengan jenis jahe lainnya, terutama jika ditinjau dari segi kandungan senyawa kimia dalam rimpangnya, yang terdiri dari zat gingerol, oleoresin, dan minyak atsiri yang tinggi (Herlina et al., 2002). Jahe merah memiliki aroma yang tajam dan rasanya sangat tajam sehingga cocok dijadikan minuman. Aroma pada jahe merah tersebut disebabkan oleh adanya minyak atsiri pada jahe merah tersebut. Kandungan zingiberene pada minyak atsiri jahe merah adalah 21,38\% pada perlakuan basah dan 19,61\% kondisi kering (Wulandari, 2009). Gingerol pada jahe merah memiliki aktivitas antibakteri, antioksidan, antikarsinogenik, antiinflamasi, antimutagenik, dan antitumor (Sari et al., 2013, Ghasemzadeh et al., 2016; Shimoda et al., 2010; Kim et al., 2005). Jahe merah dapat menghambat pertumbuhan bakteri patogen yaitu Staphylococcus aureus dan Escherichia coli (Handrianto, 2016).

Pelatihan pembuatan wedang jahe merah (Gambar 2) merupakan kegiatan pengabdian kepada masyarakat bertujuan untuk memberikan cara pembuatan wedang jahe merah agar anak-anak di LKSA Anak Gembira dapat membuatnya secara mandiri dan memperoleh manfaat wedang jahe merah tersebut bagi kesehatan ketika mengonsumsinya selama pandemi Covid-19. Prosedur pembuatan wedang jahe merah dapat dilihat pada Gambar 3. Minuman wedang jahe merah yang dihasilkan dapat dilihat pada Gambar 4. Anak-anak panti asuhan di LKSA Anak Gembira sangat antusias dalam kegiatan pelatihan tersebut dan mencicipi/meminum wedang jahe merah yang telah dibuat oleh mitra dalam kegiatan pelatihan dan menjawab kuesioner tentang wedang jahe merah yang dihasilkan (Gambar 5). Oleh karena itu, tim pengabdian kepada masyarakat USU berharap mitra rutin membuat dan mengonsumsi wedang jahe merah agar kesehatan dan imun tubuh anakanak di LKSA Anak Gembira dapat terjaga selama pandemi Covid-19 . 
Karina, et al Red ginger wedang to strengthen immune system against covid-19 of children living in an orphanage
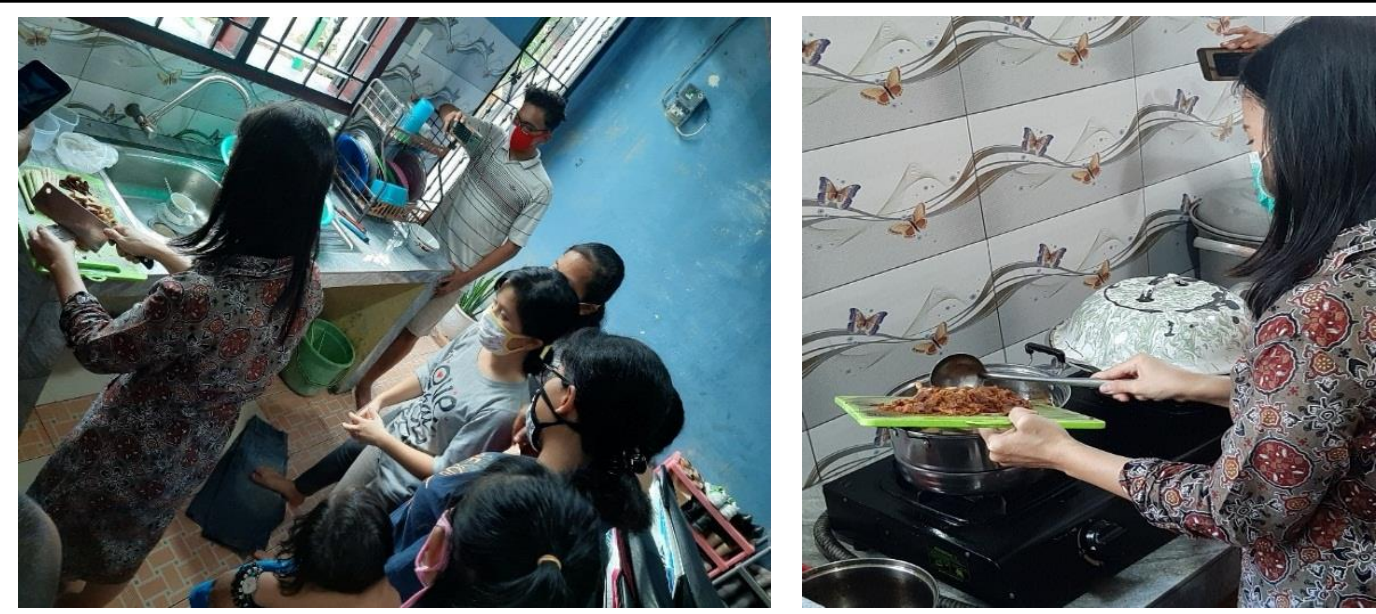

Gambar 2. Pelatihan praktik pembuatan wedang jahe merah di LKSA Anak Gembira

Jahe merah dikupas, dicuci sampai bersih, dan dipotong-potong dan ditimbang sebanyak 100 gram atau sesuai selera

Sereh dicuci dan digeprek sebanyak 4 batang dan dipotong bagi dua

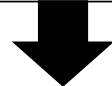

Kayu manis dicuci dan ditimbang sebanyak 10 gram atau secukupnya

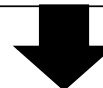

Gula merah diiris dan ditimbang sebanyak 200 gram atau secukupnya

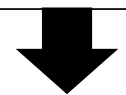

Dicampur jahe merah, sereh, kayu manis, dan gula merah ke dalam air sebanyak 1 liter
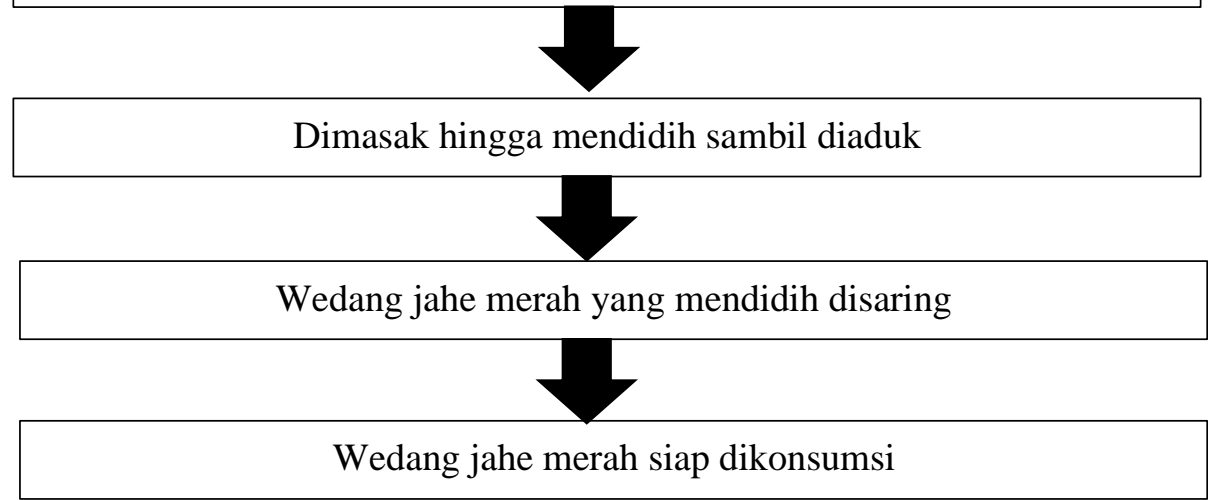

Gambar 3. Prosedur pembuatan wedang jahe merah 

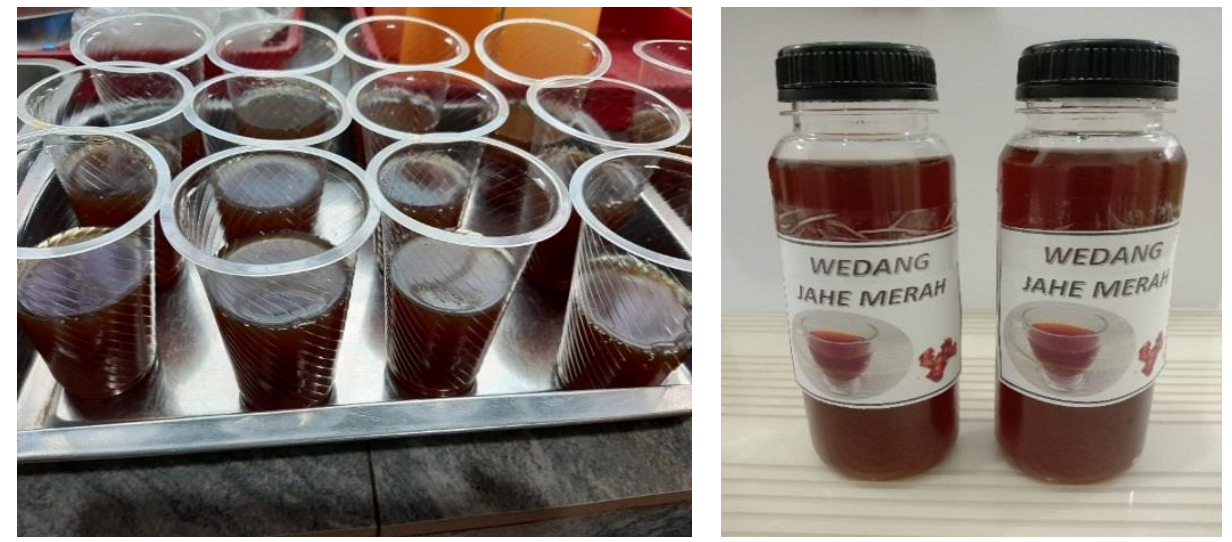

Gambar 4. Wedang jahe merah yang dihasilkan dalam kegiatan pelatihan

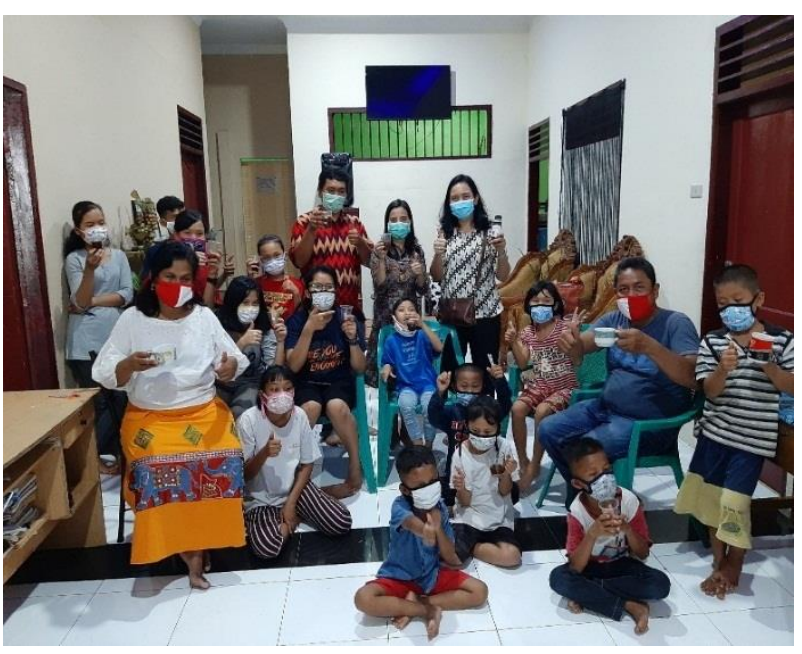

(a)

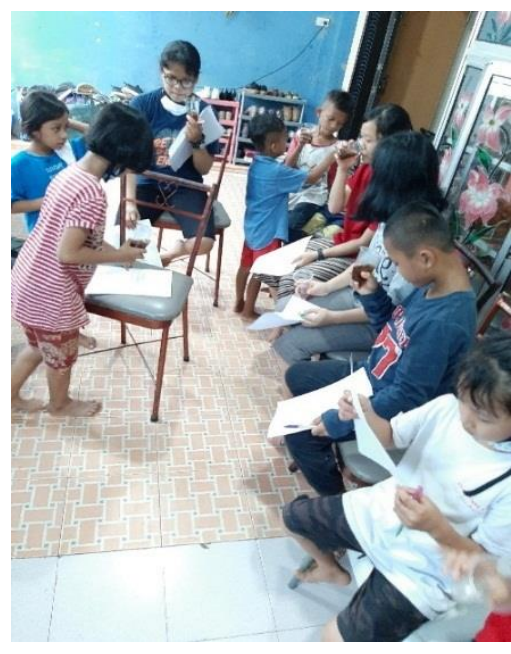

(b)

Gambar 5. Mitra bersama tim pengabdian kepada masyarakat meminum wedang jahe merah (a) dan menjawab kuesioner (b)

Hasil kuesioner yang dilakukan oleh anak-anak panti asuhan LKSA Anak Gembira dapat dilihat pada Tabel 1. Dengan adanya pelatihan pembuatan wedang jahe tersebut, anak-anak panti asuhan LKSA Anak Gembira menjadi 93\% mengetahui manfaat wedang jahe merah dari sebelumnya hanya $40 \%$ yang tidak tahu manfaat wedang jahe merah. Anak-anak panti asuhan menyukai minuman wedang jahe merah yang dihasilkan saat pelatihan sebesar $87 \%$ dan tidak menyukai wedang jahe merah sebesar $13 \%$.

Tabel 1. Hasil kuesioner wedang jahe oleh anak panti asuhan LKSA Anak Gembira

\begin{tabular}{|l|c|c|}
\hline \multirow{2}{*}{ Keterangan } & \multicolumn{2}{c|}{ Hasil } \\
\cline { 2 - 3 } & Ya & Tidak \\
\hline Responden mengetahui jahe merah sebelum pelatihan & $73 \%$ & $27 \%$ \\
\hline Responden mengetahui wedang jahe merah sebelum pelatihan & $40 \%$ & $60 \%$ \\
\hline Responden mengetahui wedang jahe merah sesudah pelatihan & $100 \%$ & $0 \%$ \\
\hline Responden pernah meminum wedang jahe merah sebelum pelatihan & $20 \%$ & $80 \%$ \\
\hline $\begin{array}{l}\text { Responden menyukai minuman wedang jahe merah yang dihasilkan saat } \\
\text { pelatihan }\end{array}$ & $87 \%$ & $13 \%$ \\
\hline Responden mengetahui manfaat wedang jahe sebelum pelatihan & $40 \%$ & $60 \%$ \\
\hline
\end{tabular}


Responden mengetahui manfaat wedang jahe sesudah pelatihan $93 \%$ $7 \%$

Respon anak-anak panti asuhan setelah mengonsumsi wedang jahe merah yang dihasilkan saat pelatihan adalah $80 \%$ merasa wedang jahe merah tersebut enak, $7 \%$ merasa wedang jahe merah tersebut biasa saja, dan $13 \%$ tidak suka wedang jahe merah tersebut, dapat dilihat pada Gambar 6. Respon anak-anak merasa wedang jahe tidak enak disebabkan oleh adanya rasa pedas di mulut saat mengonsumsi wedang jahe merah tersebut. Oleh karena itu, harapan anak-anak panti asuhan agar produk wedang jahe merah adalah $67 \%$ adanya varian rasa dan $33 \%$ sajian lebih menarik dari wedang jahe merah tersebut.

Respon terhadap wedang jahe merah

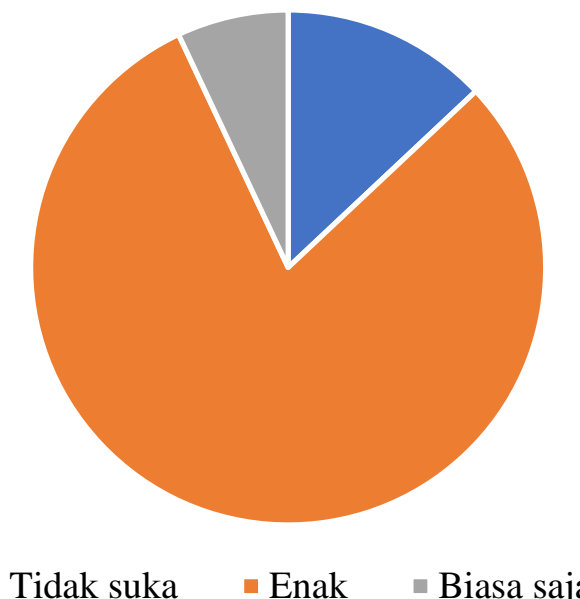

Gambar 6. Respon anak-anak panti asuhan LKSA Anak Gembira terhadap wedang jahe merah yang dihasilkan

Kegiatan pengabdian kepada masyarakat ini juga memberikan bantuan bibit tanaman jahe merah (Gambar 7). Bibit tanaman jahe merah tersebut akan ditanaman di pekarangan panti asuhan LKSA Anak Gembira sehingga dapat menghasilkan jahe merah yang dapat dimanfaatkan dalam membuat wedang jahe merah sehingga mitra tidak terkendala dalam mendapatkan bahan baku (jahe merah) dalam membuat wedang jahe merah tersebut.

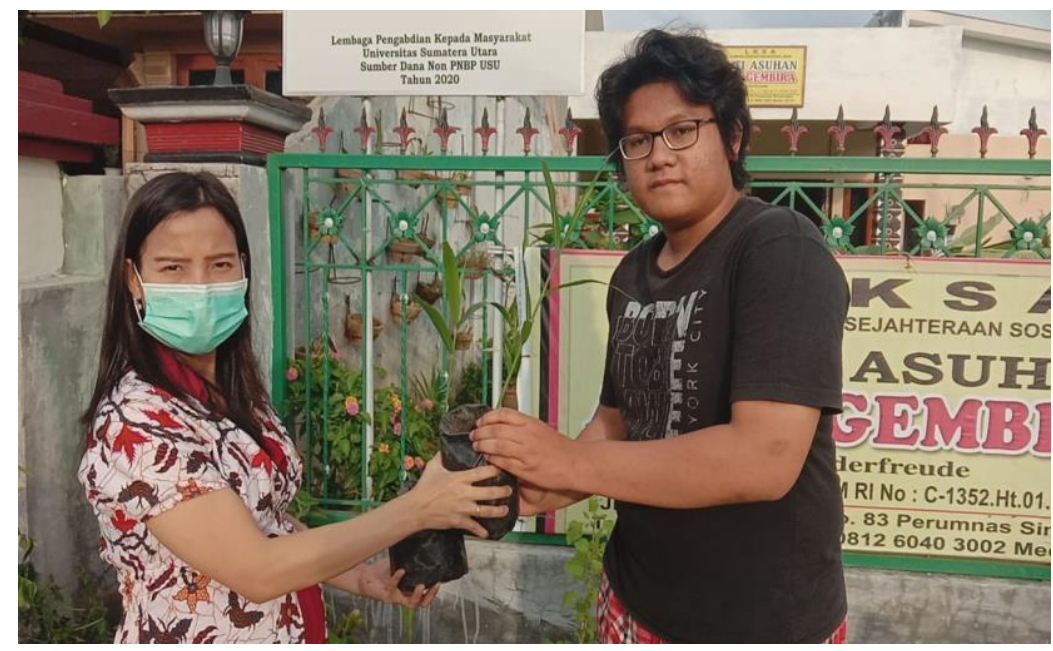

Gambar 7. Tim pengabdian kepada masyarakat memberikan bantuan bibit jahe merah 
Mewabahnya virus Corona di lingkungan tersebut menyebabkan anak-anak panti asuhan di LKSA Anak Gembira harus tetap berada di rumah sesuai anjuran pemerintah sehingga aktivitas belajar dan bermain dilakukan di dalam rumah. Akan tetapi, jumlah anak-anak panti asuhan sebanyak 22 orang merupakan jumlah yang cukup banyak untuk berada di dalam rumah yang sangat mudah untuk terjadi penularan. Berdasarkan sumber dari WHO [World Health Organization] Indonesia (2020) bahwa beberapa orang yang terinfeksi tidak menunjukkan gejala apa pun dan tetap merasa sehat. Oleh karena itu, perlu dilakukan pengarahan untuk menjaga jarak saat berinteraksi di dalam rumah dan tetap menjaga kebersihan tangan di LKSA Anak Gembira agar terhindar dari penularan virus Covid-19. Tim pengabdian kepada masyarakat memberikan bantuan sabun cuci tangan cair, hand sanitizer, dan masker kain.

Dalam kegiatan pemberian masker kain, tim pengabdian kepada masyarakat juga memberitahu cara penggunaan masker kain tersebut adalah sebagai berikut:

1. Mencuci tangan dengan sabun atau hand sanitizer berbasis alkohol sebelum menggunakan masker kain.

2. Masker kain yang digunakan harus menutupi bagian hidung dan mulut tanpa ada celah.

3. Tidak boleh menyentuh masker kain selama dipakai/digunakan.

4. Penggunaan masker kain tidak boleh lebih dari 4 jam.

5. Ketika membuka masker tidak boleh menyentuh bagian depan masker kain dan setelah selesai membuka, bersihkan kembali tangan dengan sabun atau hand sanitizer berbasis alkohol.

6. Setelah penggunaan, masker kain disterilisasikan atau dicuci dengan air sabun atau merebus dengan air mendidih selama 10 menit.

Pada kesempatan yang sama, tim pengabdian kepada masyarakat memberikan bantuan kotak obat dan bantuan bahan pangan (sembako) yang diperlukan oleh mitra dalam mencegah penyebaran Covid-19 di LKSA Anak Gembira (Gambar 6). Paket sembako yang diberikan adalah beras, telur, susu, gula pasir, dan minyak goreng yang dilaksanakan pada bulan Juli dan Agustus 2020. Pemberian bantuan bahan pangan tersebut bertujuan membantu perekonomian LKSA Anak Gembira selama pandemi Covid-19 ini sehingga kesehatan anak-anak panti asuhan tetap terjaga.
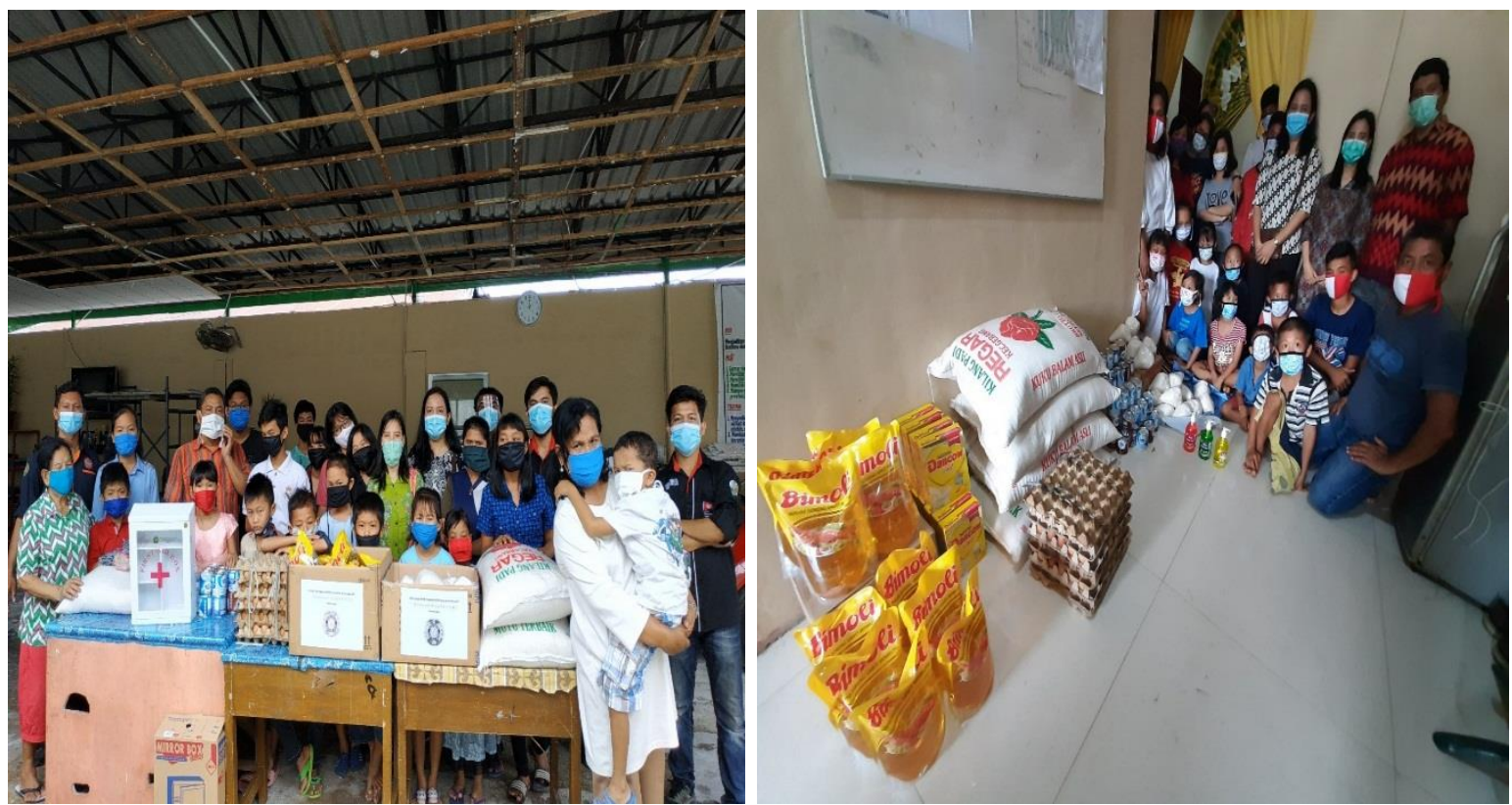

Gambar 7. Bantuan tim pengabdian kepada masyarakat kepada mitra

\section{KESIMPULAN}


Dalam kegiatan pengabdian kepada masyarakat ini, mitra beserta anak-anak panti asuhan di LKSA Anak Gembira sangat antusias untuk dilatih dalam kegiatan pelatihan wedang jahe merah tersebut. Hasil kuesioner yang didapat setelah pelatihan tersebut $93 \%$ responden mengetahui manfaat wedang jahe merah dan $83 \%$ memiliki kesukaan akan wedang jahe merah. Respon terhadap wedang jahe merah adalah $80 \%$ enak, $7 \%$ biasa saja, dan $13 \%$ tidak suka. Selain itu, mitra terbantu dengan pemberian bantuan yang diberikan oleh tim pengabdian kepada masyarakat, dimana bantuan tersebut sangat bermanfaat bagi mitra dalam penerapan pencegahan penyebaran Covid-19.

\section{UCAPAN TERIMA KASIH}

Penulis mengucapkan terima kasih kepada Lembaga Pengabdian Kepada Masyarakat Universitas Sumatera Utara yang telah membiayai kegiatan pengabdian kepada masyarakat ini, dimana artikel ini merupakan salah satu luaran dari pelaksanaan Pengabdian kepada Masyarakat Sumber Dana Non PNPB Universitas Sumatera Utara sesuai dengan Surat Perjanjian Penugasan Pelaksanaan Pengabdian kepada Masyarakat Program Mono Tahun Dosen Muda Tahun Anggaran 2020 dengan Nomor: 291/UN5.2.3.2.1/PPM/2020 Tanggal 9 Juni 2020.

\section{DAFTAR PUSTAKA}

Dinas Kesehatan Kota Medan. (2020). Data per-kecamatan terkait Covid-19 Kota Medan. https://covid19.pemkomedan.go.id/index.php?page=peta (diakses 30 April 2020 dan 27 Agustus 2020).

Ghasemzadeh A., Jaafar H., Rahmat A. (2016). Variation of the phytochemical constituents and antioxidant activities of Zingiber officinale var. rubrum theilade associated with different drying methods and polyphenol oxidase activity, 21, 780-790

Handrianto, P. (2016). Uji antibakteri ekstrak jahe merah Zingiber officinale var. Rubrum terhadap Staphylococcus aureus dan Escherichia coli. Journal of Research and Technologies, 2, 1-4.

Herlina, R., Murhananto, Endah J., Listyarini, T., Pribadi, S. T. (Tim Lentera) (2002). Khasiat dan manfaat jahe merah si rimpang ajaib. Jakarta: AgroMedia Pustaka.

Kim, E. C., Min, J. K., Kim, T. Y., Lee, S. J., Yang, H. O., Han, S., Kim, Y. M., Kwon, Y. G. (2005). [6]-Gingerol, a pungent ingredient of ginger, inhibits angiogenesis in vitro and in vivo. Biochemichal and Biophysical Research Communication, 335, 300-308.

Sari, K. I. P., Periadnadi, Nasir N. (2013). Uji antimikroba esktrak segar jahe-jahean (Zingiberaceae) terhadap Staphylococcus aureus, Escherichia coli dan Candida albicans. Jurnal Biologi Universitas Andalas, 2, 20-24.

Shimoda, H., Shan S. J., Tanaka, J., Seki A., Seo J. W., Kasajima, N., . . Murakami, N. (2010) Antiinflammatory properties of red ginger (Zingiber officinale var rubra) extract and suppression of nitric oxide production by its constituents. Journal of Medicinal Food, 13, 156-162.

WHO [World Health Organization] Indonesia. (2020). Pertanyaan dan jawaban terkait Coronavirus. https://www.who.int/indonesia/news/novel-coronavirus/qa-for-public (diakses 30 April 2020).

Wulandari, Y. W. (2009). Karakteristik minyak atsiri beberapa varietas jahe (Zingiberene officinale). Jurnal Kimia dan Teknologi, 5, 43-50. 